\title{
Synthesis and biological activities of new substituted thiazoline-quinoline derivatives
}

\author{
MOSTAFA A. HUSSEIN* \\ ABDEL-HAMID N. KAFAFY \\ SAMIA G. ABDEL-MOTY \\ OLA MOHAMED F. ABOU-GHADIR \\ Department of Pharmaceutical Organic \\ Chemistry, Faculty of Pharmacy \\ Assiut University, Assiut-71526, Egypt
}

Accepted July 31, 2009
5-Acyl-8-hydroxyquinoline-2-(3'-substituted-4'-aryl-2,3-dihydrothiazol-2'-ylidene)hydrazones, 5a-e to 10a-c, were prepared by the reaction of appropriate 5-acyl-8-hydroxyquinoline-4-substituted thiosemicarbazones 3a-e and phenacyl bromides 4a-e. Structures of the new compounds were verified on the basis of spectral and elemental analyses. Twenty-eight new compounds were tested for their possible antimicrobial activities. Most of the tested compounds showed weak to moderate antibacterial activity against most of the bacterial strains used in comparison with gatifloxacin as a reference drug. The test compounds showed weak to moderate antifungal activity against tested fungi in comparison with ketoconazole as a reference drug. On the other hand, the newly synthesized compounds were tested for their anti-inflammatory effects and most of them showed good to excellent anti-inflammatory activity compared to indomethacin. Moreover, ulcerogenicity and the median lethal dose $\left(L D_{50}\right)$ of the most active anti-inflammatory compounds $\mathbf{6} \mathbf{b}$ and $9 \mathbf{e}$ were determined in mice; they were non-toxic at doses up to 400 $\mathrm{mg} \mathrm{kg}^{-1}$ after i.p. administration.

Keywords: quinoline, thiosemicarbazone, thiazoline, phenacyl bromide, antimicrobial, anti-inflammatory

Literature surveys indicate that quinoline derivatives possess diverse pharmacological activities, including antimicrobial (1), antimalarial (2), antiviral (3), antitumor (4), immunomodulatory (5), caspase-3 inhibition (6), antileishmanial (7), local anesthetic (8), antiarrhythmic (8) and anti-inflammatory activities (9). Also, thiosemicarbazones constitute one of the most versatile classes of compounds possessing a wide spectrum of activities. It has been reported that thiosemicarbazone derivatives possess antimicrobial (1, 10), antimalarial (11), antiamoebic (12) and antitumor (13) activities. They have been in the focus of interest of medicinal chemists in the past decades because of the outstanding biological activities exhibited by several derivatives incorporating the heterocyclic moiety. Similarly, it is well documented that thiazoline nucleus is associated with a vari-

\footnotetext{
* Correspondence; e-mail: mostafa1705@yahoo.com
} 
ety of pharmacological actions, including antimicrobial (10), anti-inflammatory (14), antitumor (15) and antioxidant (16) actions.

Accordingly, the present work is aimed at the design and synthesis of new thiazo-line quinoline compounds derived by cyclization of quinoline thiosemicarbazone. Moreover, the study includes testing of target compounds for their expected antimicrobial and anti-inflammatory effects.

\section{EXPERIMENTAL}

\section{Materials and equipment}

Melting points were determined on an electrothermal melting point apparatus (Stuart Scientific, SMP1, UK) and were uncorrected. Pre-coated silica gel plates (Kieselgel $0.25 \mathrm{~mm}$, 60G F254, Merck, Germany) were used for TLC to monitor the reactions using $\mathrm{CHCl}_{3} / \mathrm{CH}_{3} \mathrm{OH}$ 9:1 as the mobile phase. Visualization of the spots was effected using an ultraviolet lamp (model CM-10, Spectroline, USA) and/or iodine stain.

IR spectra were carried out as KBr discs on a Shimadzu IR-470 Spectrometer (Shimadzu, Japan). ${ }^{1} \mathrm{H}$ NMR spectra were scanned on a Varian EM-360L NMR spectrometer (60 MHz, Varian, USA). Chemical shifts are expressed in $\delta$-values (ppm) relative to tetramethylsilane (TMS) as an internal standard using $\mathrm{CDCl}_{3}$ as solvent; deuterium oxide was used for the detection of exchangeable protons.

Mass spectra were recorded with a JEOL JMS600 mass spectrometer (JEOL, Japan). Elemental microanalyses were performed on a Perkin-Elmer 240 Elemental Analyzer (Perkin-Elmer, USA).

\section{Syntheses}

The starting materials 5-acyl-8-hydroxyquinolines $\mathbf{1 a}$ and $\mathbf{1 b}(1)$ and the intermediates, 4-substituted-3-thiosemicarbazides 2a-e (17), 5-acyl-8-hydroxy-quinoline-4-substituted thiosemicarbazones 3a-f (1), and phenacyl bromides 4a-e (18) were prepared according to reported procedures.

\section{5-Acetyl-8-hydroxyquinoline-2-(3'-substituted-4'-aryl-2,3-dihydrothiazol-2'-ylidene)- -hydrazones (5a-e to 8a-e) and 5-benzoyl-8-hydroxyquinoline-2-(3'-cyclohexyl-4'- -aryl-2,3-dihydrothiazol-2'-ylidene)hydrazones (10a-c)}

A solution of the appropriate thiosemicarbazone derivative $3 \mathbf{a}-\mathbf{d}$ and $3 \mathbf{f}(0.0015 \mathrm{~mol})$, anhydrous sodium acetate $(100 \mathrm{mg}, 0.0012 \mathrm{~mol})$ and the appropriate phenacyl bromide 4a-e $(0.0015 \mathrm{~mol})$ in absolute ethanol $(30 \mathrm{~mL})$ was heated under reflux for $12-24 \mathrm{~h}$, concentrated and left overnight. The product was filtered, dried and crystallized from absolute ethanol (Scheme 1, Tables I and II). 


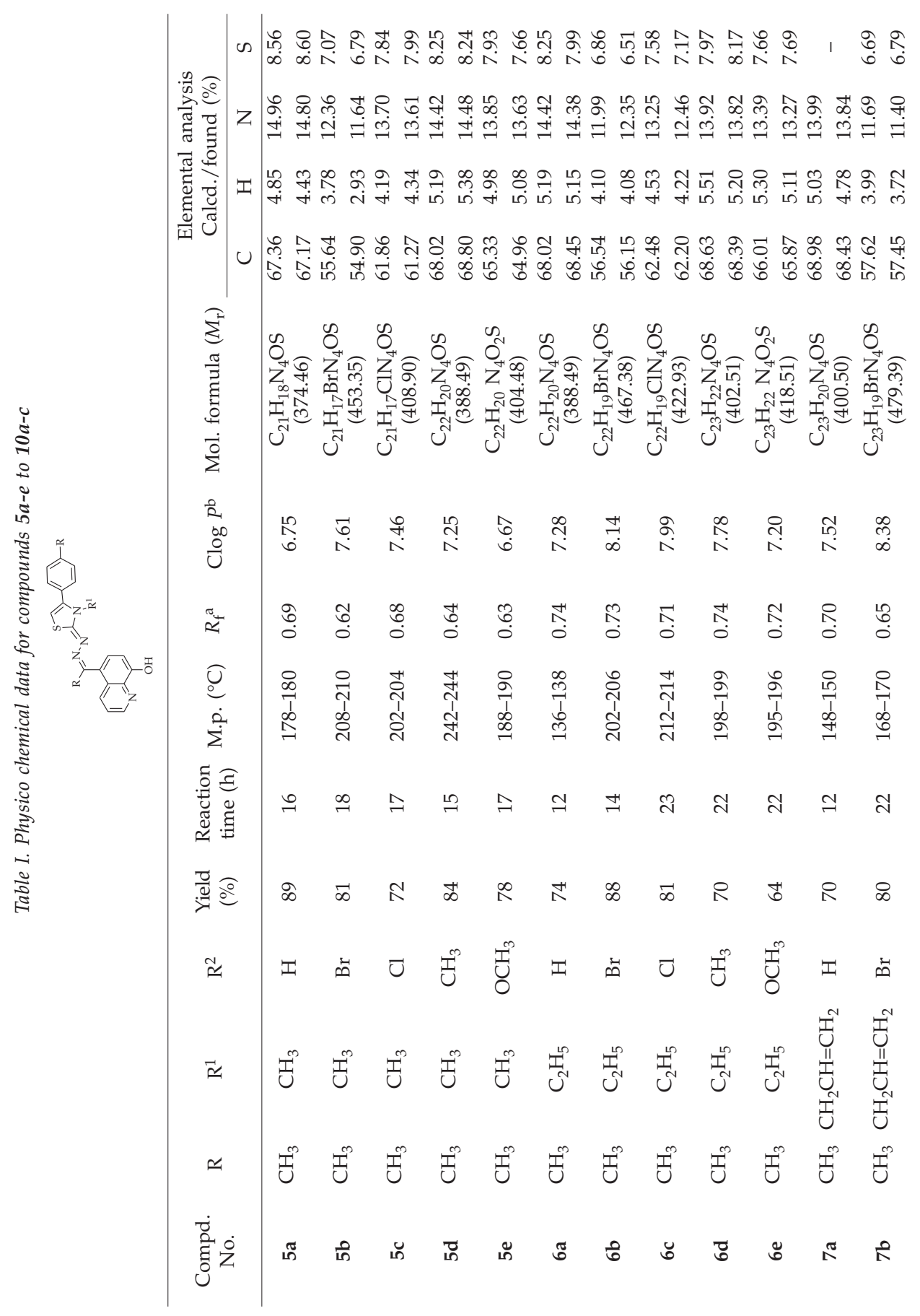




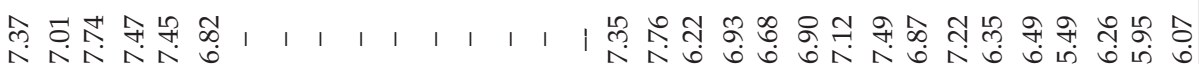

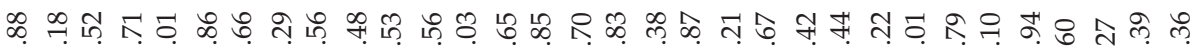

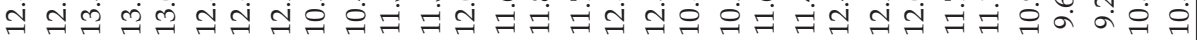

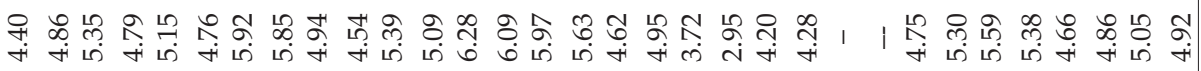

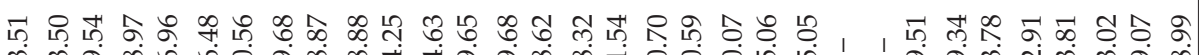

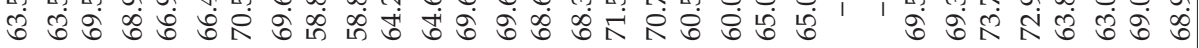

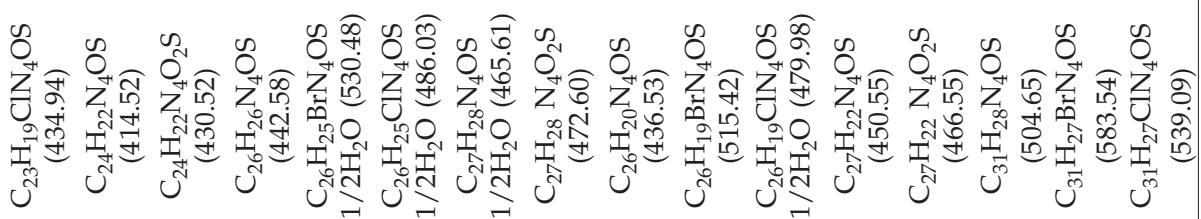
赵 గ

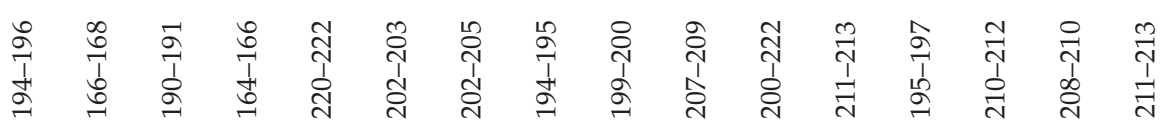
உ คำ ర

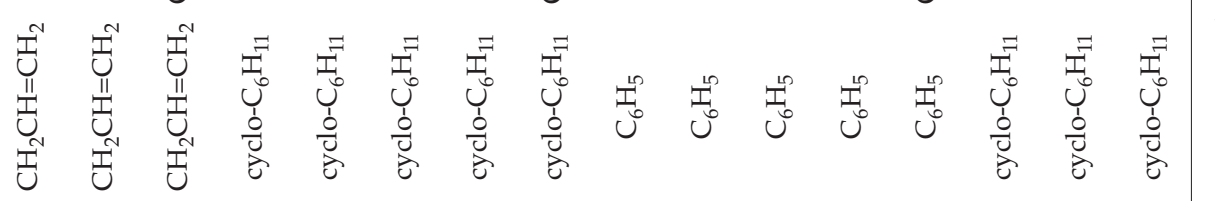

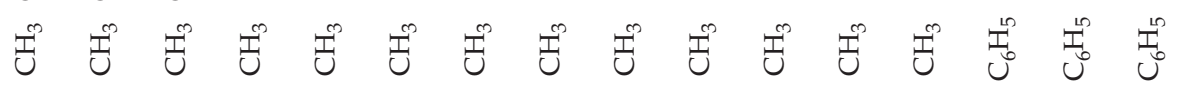

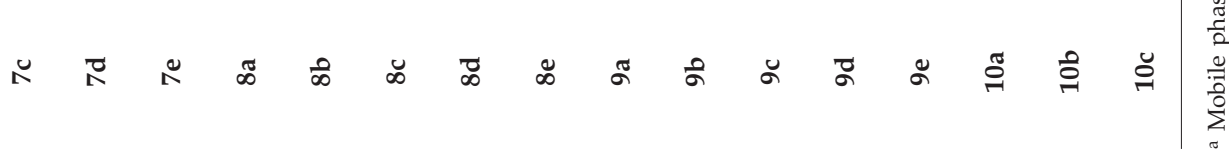


M. A. Hussein et al.: Synthesis and biological activities of new substituted thiazoline-quinoline derivatives, Acta Pharm. 59 (2009) 365-382.

5-Acetyl-8-hydroxyquinoline-2-(3'-phenyl-4'-aryl-2,3-dihydrothiazol-2'-ylidene)-hydra zones $(9 a-e)$

A solution of the thiosemicarbazone derivative $3 \mathbf{e}(0.504 \mathrm{~g}, 0.0015 \mathrm{~mol})$, anhydrous sodium acetate $(100 \mathrm{mg}, 0.0012 \mathrm{~mol})$ and the appropriate phenacyl bromide 4a-e $(0.0015$ $\mathrm{mol})$ in absolute ethanol $(30 \mathrm{~mL})$ was stirred at room temperature for $10-15 \mathrm{~h}$, concentrated and left overnight. The product was filtered, dried and crystallized from absolute ethanol (Scheme 1, Tables I and II).

\section{Antimicrobial activity}

Antibacterial activity. - The synthesized compounds 5a-e to 10a-c were tested for their antibacterial activity in vitro in comparison with gatifloxacin as a reference drug using the standard agar disc diffusion method (19) against six bacterial species: Bacillus cereus (AUMC B70), Staphylococcus aureus (AUMC B71) and Micrococcus luteus (AUMC B68) as representatives of the Gram-positive strains, while the Gram-negative strains were rep-<smiles>Oc1cccc2cccnc12</smiles><smiles>[R]C(=O)Cl</smiles><smiles>[R]C(=O)c1ccc(O)c2ncccc12</smiles>

$1 a-b$

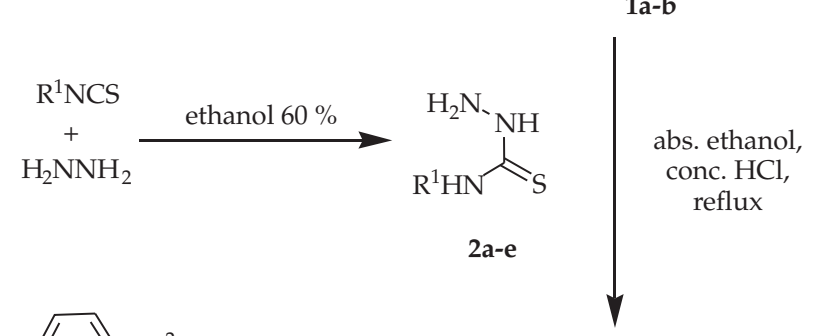<smiles>[R]/C(=N/N=c1\scc(-c2ccc([R])cc2)n1[R1])c1ccc(O)c2ncccc12</smiles><smiles>[R]c1ccc(C(=O)CBr)cc1</smiles><smiles>[14CH3]</smiles>
anhyd. sodium acetate

5a-e to $10 a-c$ abs. ethanol<smiles>[R]NC(=S)N/N=C(/[R])c1ccc(O)c2ncccc12</smiles>

R: $\mathrm{CH}_{3}$ or $\mathrm{C}_{6} \mathrm{H}_{5}$

$\mathrm{R}^{1}: \mathrm{CH}_{3}, \mathrm{C}_{2} \mathrm{H}_{5}, \mathrm{CH}_{2} \mathrm{CH}=\mathrm{CH}_{2}$, cyclo- $\mathrm{C}_{6} \mathrm{H}_{11}$ or $\mathrm{C}_{6} \mathrm{H}_{5}$ $\mathrm{R}^{2}: \mathrm{H}, \mathrm{Br}, \mathrm{Cl}, \mathrm{CH}_{3}$ or $\mathrm{OCH}_{3}$

Scheme 1 
M. A. Hussein et al.: Synthesis and biological activities of new substituted thiazoline-quinoline derivatives, Acta Pharm. 59 (2009) $365-382$.

Table II. ${ }^{1} \mathrm{H}$ NMR data for compounds $5 a-e$ to $9 a-e$ and $10 a-c$

\begin{tabular}{|c|c|c|}
\hline $\begin{array}{l}\text { Compd. } \\
\text { No. }\end{array}$ & $\begin{array}{c}\text { Mass } m / z \\
\text { (\% abundance) }\end{array}$ & ${ }^{1} \mathrm{H} \mathrm{NMR}\left(\mathrm{CDCl}_{3}, \delta \mathrm{ppm}\right)^{\mathrm{a}}$ \\
\hline $5 a$ & - & $\begin{array}{l}10.23\left(\mathrm{~d}, 1 \mathrm{H}, \mathrm{H}_{2} \text { of quinoline }\right) ; 9.47\left(\mathrm{~d}, 1 \mathrm{H}, \mathrm{H}_{4} \text { of quinoline }\right) \\
\left.\text { 8.47-7.63 (m, } 9 \mathrm{H}, \mathrm{OH}, \mathrm{H}_{3,6,7} \text { of quinoline, } \mathrm{C}_{6} \mathrm{H}_{5}\right) ; 6.42(\mathrm{~s}, 1 \mathrm{H}, \\
\mathrm{CH} \text { of thiazoline); } 3.7\left(\mathrm{~s}, 3 \mathrm{H}, \mathrm{NCH}_{3}\right) ; 2.83\left(\mathrm{~s}, 3 \mathrm{H}, \mathrm{CH}_{3}\right)\end{array}$ \\
\hline $5 b$ & $\begin{array}{l}452\left[\mathrm{M}^{+}\right](63.3 \%) \\
170\left[\mathrm{M}^{+}\right](100 \%) \\
454\left[\mathrm{M}^{+}+2\right](71.9 \%)\end{array}$ & $\begin{array}{l}10.63\left(\mathrm{~d}, 1 \mathrm{H}, \mathrm{H}_{2} \text { of quinoline }\right) ; 9.72\left(\mathrm{~d}, 1 \mathrm{H}, \mathrm{H}_{4} \text { of quinoline }\right) \text {; } \\
\text { 8.57-7.75 }\left(\mathrm{m}, 8 \mathrm{H}, \mathrm{OH}, \mathrm{H}_{3,6,7} \text { of quinoline, } \mathrm{C}_{6} \mathrm{H}_{4}\right) ; 6.60(\mathrm{~s}, 1 \mathrm{H} \text {, } \\
\mathrm{CH} \text { of thiazoline); } 3.70\left(\mathrm{~s}, 3 \mathrm{H}, \mathrm{NCH}_{3}\right) ; 2.80\left(\mathrm{~s}, 3 \mathrm{H}, \mathrm{CH}_{3}\right)\end{array}$ \\
\hline $5 c$ & - & $\begin{array}{l}10.73\left(\mathrm{~d}, 1 \mathrm{H}, \mathrm{H}_{2} \text { of quinoline); } 9.8\left(\mathrm{~d}, 1 \mathrm{H}, \mathrm{H}_{4} \text { of quinoline }\right)\right. \\
8.5-7.8\left(\mathrm{~m}, 8 \mathrm{H}, \mathrm{OH}, \mathrm{H}_{3,6,7} \text { of quinoline, } \mathrm{C}_{6} \mathrm{H}_{4}\right) ; 6.53(\mathrm{~s}, 1 \mathrm{H}, \\
\mathrm{CH} \text { of thiazoline); } 3.72\left(\mathrm{~s}, 3 \mathrm{H}, \mathrm{NCH}_{3}\right) ; 2.82\left(\mathrm{~s}, 3 \mathrm{H}, \mathrm{CH}_{3}\right)\end{array}$ \\
\hline $5 d$ & - & $\begin{array}{l}10.57\left(\mathrm{~d}, 1 \mathrm{H}, \mathrm{H}_{2} \text { of quinoline }\right) ; 9.7\left(\mathrm{~d}, 1 \mathrm{H}, \mathrm{H}_{4} \text { of quinoline }\right) \text {; } \\
8.73-7.88\left(\mathrm{~m}, 8 \mathrm{H}, \mathrm{OH}, \mathrm{H}_{3,6,7} \text { of quinoline, } \mathrm{C}_{6} \mathrm{H}_{4}\right) ; 6.56(\mathrm{~s}, 1 \mathrm{H} \text {, } \\
\mathrm{CH} \text { of thiazoline }) ; 3.73\left(\mathrm{~s}, 3 \mathrm{H}, \mathrm{NCH}_{3}\right) ; 2.83\left(\mathrm{~s}, 3 \mathrm{H}, \mathrm{CH}_{3}\right) ; 2.63 \\
\left(\mathrm{~s}, 3 \mathrm{H}, \mathrm{C}_{6} \mathrm{H}_{4}-\mathrm{CH}_{3}\right)\end{array}$ \\
\hline $5 e$ & - & $\begin{array}{l}10.25\left(\mathrm{~d}, 1 \mathrm{H}, \mathrm{H}_{2} \text { of quinoline }\right) ; 9.5\left(\mathrm{~d}, 1 \mathrm{H}, \mathrm{H}_{4} \text { of quinoline); }\right. \\
8.4-7.37\left(\mathrm{~m}, 8 \mathrm{H}, \mathrm{OH}, \mathrm{H}_{3,6,7} \text { of quinoline, } \mathrm{C}_{6} \mathrm{H}_{4}\right) ; 6.33(\mathrm{~s}, 1 \mathrm{H} \text {, } \\
\mathrm{CH} \text { of thiazoline }) ; 4.13\left(\mathrm{~s}, 3 \mathrm{H}, \mathrm{OCH}_{3}\right) ; 3.60\left(\mathrm{~s}, 3 \mathrm{H}, \mathrm{NCH}_{3}\right) ; \\
2.82\left(\mathrm{~s}, 3 \mathrm{H}, \mathrm{CH}_{3}\right)\end{array}$ \\
\hline $6 a$ & - & 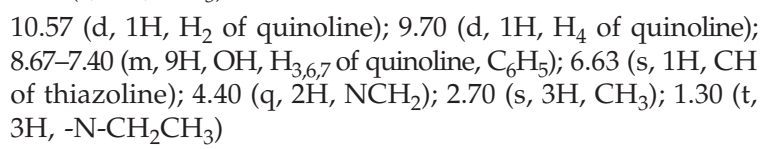 \\
\hline $6 b$ & - & 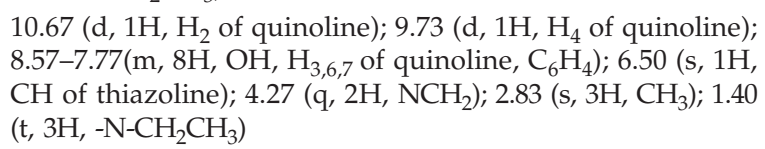 \\
\hline $6 c$ & $\begin{array}{l}422\left[\mathrm{M}^{+}\right](54.2 \%) \\
170\left[\mathrm{M}^{+}\right](100 \%) \\
424\left[\mathrm{M}^{+}+2\right](23.7 \%)\end{array}$ & 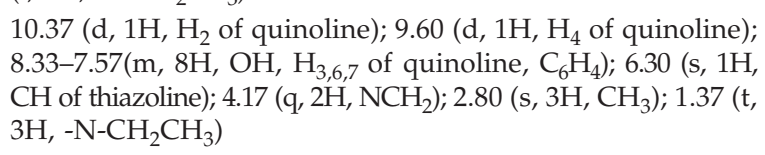 \\
\hline $6 d$ & - & 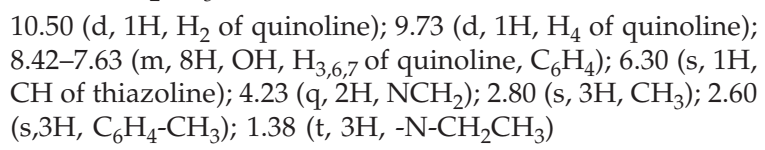 \\
\hline $6 e$ & - & 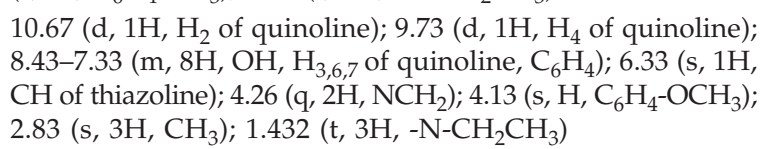 \\
\hline $7 a$ & $400\left[\mathrm{M}^{+}\right](100 \%)$ & $\begin{array}{l}10.5\left(\mathrm{~d}, 1 \mathrm{H}, \mathrm{H}_{2} \text { of quinoline); } 9.73\left(\mathrm{~d}, 1 \mathrm{H}, \mathrm{H}_{4} \text { of quinoline); }\right.\right. \\
8.93-7.67\left(\mathrm{~m}, 9 \mathrm{H}, \mathrm{OH}, \mathrm{H}_{3,6,7} \text { of quinoline, } \mathrm{C}_{6} \mathrm{H}_{5}\right) ; 7.00-6.00(\mathrm{~m}, \\
\left.1 \mathrm{H}, \mathrm{CH}=\mathrm{CH}_{2}\right) ; 6.5(\mathrm{~s}, 1 \mathrm{H}, \mathrm{CH} \text { of thiazoline }) ; 5.9-5.33(\mathrm{dd}, \\
\left.2 \mathrm{H}, \mathrm{CH}=\mathrm{CH}_{2}\right) ; 4.92\left(\mathrm{~d}, 2 \mathrm{H}, \mathrm{NCH}_{2}\right) ; 2.90\left(\mathrm{~s}, 3 \mathrm{H}, \mathrm{CH}_{3}\right)\end{array}$ \\
\hline $7 \mathrm{~b}$ & - & $\begin{array}{l}10.33\left(\mathrm{~d}, 1 \mathrm{H}, \mathrm{H}_{2} \text { of quinoline }\right) ; 9.58\left(\mathrm{~d}, 1 \mathrm{H}, \mathrm{H}_{4} \text { of quinoline); }\right. \\
8.6-7.7\left(\mathrm{~m}, 8 \mathrm{H}, \mathrm{OH}, \mathrm{H}_{3,6,7} \text { of quinoline, } \mathrm{C}_{6} \mathrm{H}_{4}\right) ; 7.00-6.00(\mathrm{~m}, \\
\left.1 \mathrm{H}, \mathrm{CH}=\mathrm{CH}_{2}\right) ; 6.53(\mathrm{~s}, 1 \mathrm{H}, \mathrm{CH} \text { of thiazoline }) ; 5.93-5.33(\mathrm{dd} \text {, } \\
\left.2 \mathrm{H}, \mathrm{CH}=\mathrm{CH}_{2}\right) ; 4.9\left(\mathrm{~d}, 2 \mathrm{H}, \mathrm{NCH}_{2}\right) ; 2.83\left(\mathrm{~s}, 3 \mathrm{H}, \mathrm{CH}_{3}\right)\end{array}$ \\
\hline
\end{tabular}




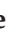

$434\left[\mathrm{M}^{+}\right](100 \%)$, $436\left[\mathrm{M}^{+}+2\right](36.1 \%)$

$520\left[\mathrm{M}^{+}\right](14.8 \%)$, $55\left[\mathrm{M}^{+}\right](100 \%)$, $522\left[\mathrm{M}^{+}+2\right](14.9 \%)$

d a $10.33\left(\mathrm{~d}, 1 \mathrm{H}, \mathrm{H}_{2}\right.$ of quinoline); $9.53\left(\mathrm{~d}, 1 \mathrm{H}, \mathrm{H}_{4}\right.$ of quinoline); 8.47-7.63 (m, 8H, OH, $\mathrm{H}_{3,6,7}$ of quinoline, $\left.\mathrm{C}_{6} \mathrm{H}_{4}\right) ; 6.80-6.00(\mathrm{~m}$, $\left.1 \mathrm{H}, \mathrm{CH}=\mathrm{CH}_{2}\right) ; 6.50(\mathrm{~s}, 1 \mathrm{H}, \mathrm{CH}$ of thiazoline); $5.80-5.16(\mathrm{dd}$, $\left.2 \mathrm{H}, \mathrm{CH}=\mathrm{CH}_{2}\right) ; 4.80\left(\mathrm{~d}, 2 \mathrm{H}, \mathrm{NCH}_{2}\right) ; 2.73\left(\mathrm{~s}, 3 \mathrm{H}, \mathrm{CH}_{3}\right)$ $10.17\left(\mathrm{~d}, 1 \mathrm{H}, \mathrm{H}_{2}\right.$ of quinoline); $9.40\left(\mathrm{~d}, 1 \mathrm{H}, \mathrm{H}_{4}\right.$ of quinoline); 8.53-7.37 (m, 8H, OH, $\mathrm{H}_{3,6,7}$ of quinoline, $\left.\mathrm{C}_{6} \mathrm{H}_{4}\right) ; 6.63-6.1$ $\left(\mathrm{m}, 1 \mathrm{H}, \mathrm{CH}=\mathrm{CH}_{2}\right) ; 6.30(\mathrm{~s}, 1 \mathrm{H}, \mathrm{CH}$ of thiazoline $) ; 5.70-5.16$ $\left(\mathrm{dd}, 2 \mathrm{H}, \mathrm{CH}=\mathrm{CH}_{2}\right) ; 4.7\left(\mathrm{~d}, 2 \mathrm{H}, \mathrm{NCH}_{2}\right) ; 2.73\left(\mathrm{~s}, 3 \mathrm{H}, \mathrm{CH}_{3}\right) ; 2.53$ (s, $3 \mathrm{H}, \mathrm{C}_{6} \mathrm{H}_{4} \mathrm{CH}_{3}$ )

$10.30\left(\mathrm{~d}, 1 \mathrm{H}, \mathrm{H}_{2}\right.$ of quinoline); $9.50\left(\mathrm{~d}, 1 \mathrm{H}, \mathrm{H}_{4}\right.$ of quinoline); 8.56-7.4 (m, 8H, OH, $\mathrm{H}_{3,6,7}$ of quinoline, $\left.\mathrm{C}_{6} \mathrm{H}_{4}\right) ; 6.93-6.23(\mathrm{~m}$, $\left.1 \mathrm{H}, \mathrm{CH}=\mathrm{CH}_{2}\right) ; 6.4(\mathrm{~s}, 1 \mathrm{H}, \mathrm{CH}$ of thiazoline); $5.9-5.33(\mathrm{dd}, 2 \mathrm{H}$, $\left.\mathrm{CH}=\mathrm{CH}_{2}\right) ; 4.86\left(\mathrm{~d}, 2 \mathrm{H}, \mathrm{NCH}_{2}\right) ; 4.23$ (s, 3H, $\left.\mathrm{OCH}_{3}\right) ; 2.86$ (s, $\left.3 \mathrm{H}, \mathrm{CH}_{3}\right)$

$10.20\left(\mathrm{~d}, 1 \mathrm{H}, \mathrm{H}_{2}\right.$ of quinoline); $9.33\left(\mathrm{~d}, 1 \mathrm{H}, \mathrm{H}_{4}\right.$ of quinoline); 8.70-7.37 (m, 9H, OH, $\mathrm{H}_{3,6,7}$ of quinoline, $\left.\mathrm{C}_{6} \mathrm{H}_{5}\right) ; 6.20(\mathrm{~s}, 1 \mathrm{H}$, $\mathrm{CH}$ of thiazoline); $4.33-3.67$ (m, $1 \mathrm{H}, \mathrm{NCH}$ of cyclohexyl); 2.77 $\left(\mathrm{s}, 3 \mathrm{H}, \mathrm{CH}_{3}\right) ; 3.34-0.13\left(\mathrm{~m}, 10 \mathrm{H},\left(\mathrm{CH}_{2}\right)_{5}\right.$ of cyclohexyl)

$10.17\left(\mathrm{~d}, 1 \mathrm{H}, \mathrm{H}_{2}\right.$ of quinoline $) ; 9.40\left(\mathrm{~d}, 1 \mathrm{H}, \mathrm{H}_{4}\right.$ of quinoline); 8.37-7.53 (m, 8H, OH, $\mathrm{H}_{3,6,7}$ of quinoline, $\left.\mathrm{C}_{6} \mathrm{H}_{4}\right) ; 6.27(\mathrm{~s}, 1 \mathrm{H}$, $\mathrm{CH}$ of thiazoline); $4.30-3.63(\mathrm{~m}, 1 \mathrm{H}, \mathrm{NCH}$ of cyclohexyl); 2.80 $\left(\mathrm{s}, 3 \mathrm{H}, \mathrm{CH}_{3}\right) ; 3.47-0.80\left(\mathrm{~m}, 10 \mathrm{H},\left(\mathrm{CH}_{2}\right)_{5}\right.$ of cyclohexyl)

10.23 (d, $1 \mathrm{H}, \mathrm{H}_{2}$ of quinoline); $9.40\left(\mathrm{~d}, 1 \mathrm{H}, \mathrm{H}_{4}\right.$ of quinoline); 8.40-7.40 (m, 8H, OH, $\mathrm{H}_{3,6,7}$ of quinoline, $\left.\mathrm{C}_{6} \mathrm{H}_{4}\right) ; 6.27(\mathrm{~s}, 1 \mathrm{H}$, $\mathrm{CH}$ of thiazoline); 4.37-3.07 (m, $1 \mathrm{H}, \mathrm{NCH}$ of cyclohexyl); 2.80 $\left(\mathrm{s}, 3 \mathrm{H}, \mathrm{CH}_{3}\right) ; 3.40-0.80\left(\mathrm{~m}, 10 \mathrm{H},\left(\mathrm{CH}_{2}\right)_{5}\right.$ of cyclohexyl) $10.30\left(\mathrm{~d}, 1 \mathrm{H}, \mathrm{H}_{2}\right.$ of quinoline); $9.47\left(\mathrm{~d}, 1 \mathrm{H}, \mathrm{H}_{4}\right.$ of quinoline); 8.37-7.60 (m, 8H, OH, $\mathrm{H}_{3,6,7}$ of quinoline, $\left.\mathrm{C}_{6} \mathrm{H}_{4}\right) ; 6.27(\mathrm{~s}, 1 \mathrm{H}$, $\mathrm{CH}$ of thiazoline); $4.50-3.80(\mathrm{~m}, 1 \mathrm{H}, \mathrm{NCH}$ of cyclohexyl); $2.83\left(\mathrm{~s}, 3 \mathrm{H}, \mathrm{CH}_{3}\right) ; 2.60\left(\mathrm{~s}, 3 \mathrm{H}, \mathrm{C}_{6} \mathrm{H}_{4} \mathrm{CH}_{3}\right) ; 3.50-0.80(\mathrm{~m}, 10 \mathrm{H}$, $\left(\mathrm{CH}_{2}\right)_{5}$ of cyclohexyl)

$10.30\left(\mathrm{~d}, 1 \mathrm{H}, \mathrm{H}_{2}\right.$ of quinoline); $9.53\left(\mathrm{~d}, 1 \mathrm{H}, \mathrm{H}_{4}\right.$ of quinoline); 8.50-7.40 (m, 8H, OH, $\mathrm{H}_{3,6,7}$ of quinoline, $\left.\mathrm{C}_{6} \mathrm{H}_{4}\right) ; 6.27(\mathrm{~s}, 1 \mathrm{H}$, $\mathrm{CH}$ of thiazoline); $4.18\left(\mathrm{~s}, 3 \mathrm{H}, \mathrm{OCH}_{3}\right) ; 4.47-3.80(\mathrm{~m}, 1 \mathrm{H}, \mathrm{NCH}$ of cyclohexyl); $2.85\left(\mathrm{~s}, 3 \mathrm{H}, \mathrm{CH}_{3}\right) ; 3.53-0.83\left(\mathrm{~m}, 10 \mathrm{H},\left(\mathrm{CH}_{2}\right)_{5}\right.$ of cyclohexyl)

$10.30\left(\mathrm{~d}, 1 \mathrm{H}, \mathrm{H}_{2}\right.$ of quinoline); $9.60\left(\mathrm{~d}, 1 \mathrm{H}, \mathrm{H}_{4}\right.$ of quinoline); 8.50-7.60 (m, 14H, OH, $\mathrm{H}_{3,6,7}$ of quinoline, $\left.\mathrm{NC}_{6} \mathrm{H}_{5}, \mathrm{C}_{6} \mathrm{H}_{5}\right)$; $6.70\left(\mathrm{~s}, 1 \mathrm{H}, \mathrm{CH}\right.$ of thiazoline); $2.63\left(\mathrm{~s}, 3 \mathrm{H}, \mathrm{CH}_{3}\right)$

$10.23\left(\mathrm{~d}, 1 \mathrm{H}, \mathrm{H}_{2}\right.$ of quinoline); $9.43\left(\mathrm{~d}, 1 \mathrm{H}, \mathrm{H}_{4}\right.$ of quinoline); 8.40-7.40 (m, 13H, OH, $\mathrm{H}_{3,6,7}$ of quinoline, $\left.\mathrm{NC}_{6} \mathrm{H}_{5}, \mathrm{C}_{6} \mathrm{H}_{4}\right)$; $6.63\left(\mathrm{~s}, 1 \mathrm{H}, \mathrm{CH}\right.$ of thiazoline); $2.63\left(\mathrm{~s}, 3 \mathrm{H}, \mathrm{CH}_{3}\right)$

$10.17\left(\mathrm{~d}, 1 \mathrm{H}, \mathrm{H}_{2}\right.$ of quinoline); $9.43\left(\mathrm{~d}, 1 \mathrm{H}, \mathrm{H}_{4}\right.$ of quinoline); 8.28-7.38 (m, $13 \mathrm{H}, \mathrm{OH}, \mathrm{H}_{3,6,7}$ of quinoline, $\left.\mathrm{NC}_{6} \mathrm{H}_{5}, \mathrm{C}_{6} \mathrm{H}_{4}\right) ; 6.60$ (s, $1 \mathrm{H}, \mathrm{CH}$ of thiazoline); $2.60\left(\mathrm{~s}, 3 \mathrm{H}, \mathrm{CH}_{3}\right)$

$10.25\left(\mathrm{~d}, 1 \mathrm{H}, \mathrm{H}_{2}\right.$ of quinoline); $9.50\left(\mathrm{~d}, 1 \mathrm{H}, \mathrm{H}_{4}\right.$ of quinoline); 8.37-7.43 (m, 13H, OH, $\mathrm{H}_{3,6,7}$ of quinoline, $\left.\mathrm{NC}_{6} \mathrm{H}_{5}, \mathrm{C}_{6} \mathrm{H}_{4}\right)$; 6.37 (s, 1H, CH of thiazoline); $2.60\left(\mathrm{~s}, 3 \mathrm{H}, \mathrm{CH}_{3}\right) ; 2.43(\mathrm{~s}, 3 \mathrm{H}$, $\mathrm{C}_{6} \mathrm{H}_{4} \mathrm{CH}_{3}$ ) 


\begin{tabular}{|c|c|c|}
\hline $9 e$ & - & $\begin{array}{l}10.20\left(\mathrm{~d}, 1 \mathrm{H}, \mathrm{H}_{2} \text { of quinoline }\right) ; 9.47\left(\mathrm{~d}, 1 \mathrm{H}, \mathrm{H}_{4} \text { of quinoline }\right) \text {; } \\
8.37-7.10\left(\mathrm{~m}, 13 \mathrm{H}, \mathrm{OH}, \mathrm{H}_{3,6,7} \text { of quinoline, } \mathrm{NC}_{6} \mathrm{H}_{5}, \mathrm{C}_{6} \mathrm{H}_{4}\right) ; 6.50 \\
(\mathrm{~s}, 1 \mathrm{H}, \mathrm{CH} \text { of thiazoline }) ; 4.03\left(\mathrm{~s}, 3 \mathrm{H}, \mathrm{OCH}_{3}\right) ; 2.60\left(\mathrm{~s}, 3 \mathrm{H}, \mathrm{CH}_{3}\right)\end{array}$ \\
\hline $10 a$ & - & $\begin{array}{l}9.67\left(\mathrm{~d}, 1 \mathrm{H}, \mathrm{H}_{2} \text { of quinoline }\right) ; 8.70\left(\mathrm{~d}, 1 \mathrm{H}, \mathrm{H}_{4} \text { of quinoline); }\right. \\
8.73-7.70\left(\mathrm{~m}, 14 \mathrm{H}, \mathrm{OH}, \mathrm{H}_{3,6,7} \text { of quinoline, } 2 \mathrm{C}_{6} \mathrm{H}_{5}\right) ; 6.33(\mathrm{~s}, \\
1 \mathrm{H}, \mathrm{CH} \text { of thiazoline }) ; 3.90-3.23(\mathrm{~m}, 1 \mathrm{H}, \mathrm{NCH} \text { of cyclohexyl); } \\
2.60-0.23\left(\mathrm{~m}, 10 \mathrm{H},\left(\mathrm{CH}_{2}\right)_{5} \text { of cyclohexyl) }\right.\end{array}$ \\
\hline $10 \mathrm{~b}$ & - & $\begin{array}{l}9.40\left(\mathrm{~d}, 1 \mathrm{H}, \mathrm{H}_{2} \text { of quinoline }\right) ; 8.80-7.43\left(\mathrm{~m}, 14 \mathrm{H}, \mathrm{OH}, \mathrm{H}_{3,4,6,7}\right. \\
\left.\text { of quinoline, } \mathrm{C}_{6} \mathrm{H}_{5}, \mathrm{C}_{6} \mathrm{H}_{4}\right) ; 6.23(\mathrm{~s}, 1 \mathrm{H}, \mathrm{CH} \text { of thiazoline); } \\
4.20-3.13(\mathrm{~m}, 1 \mathrm{H}, \mathrm{NCH} \text { of cyclohexyl);2.40-0.53 (m, 10H, } \\
\left(\mathrm{CH}_{2}\right)_{5} \text { of cyclohexyl) }\end{array}$ \\
\hline $10 \mathrm{c}$ & $\begin{array}{l}538\left[\mathrm{M}^{+}\right](54.6 \%) \\
247\left[\mathrm{M}^{+}\right](100 \%) \\
540\left[\mathrm{M}^{+}+2\right](23.7 \%)\end{array}$ & $\begin{array}{l}9.47\left(\mathrm{~d}, 1 \mathrm{H}, \mathrm{H}_{2} \text { of quinoline); } 8.90-7.57\left(\mathrm{~m}, 14 \mathrm{H}, \mathrm{OH}, \mathrm{H}_{3,4,6,7} \text { of }\right.\right. \\
\left.\text { quinoline, } \mathrm{C}_{6} \mathrm{H}_{5}, \mathrm{C}_{6} \mathrm{H}_{4}\right) ; 6.33(\mathrm{~s}, 1 \mathrm{H}, \mathrm{CH} \text { of thiazoline }) ; 4.13-3.23 \\
\text { (m, } 1 \mathrm{H}, \mathrm{NCH} \text { of cyclohexyl); } 2.63-0.67\left(\mathrm{~m}, 10 \mathrm{H},\left(\mathrm{CH}_{2}\right)_{5} \text { of cy- }\right. \\
\text { clohexyl) }\end{array}$ \\
\hline
\end{tabular}

a Proton of $\mathrm{OH}$ is exchangeable with $\mathrm{D}_{2} \mathrm{O}$.

resented by Escherichia coli (AUMC B69), Pseudomonas aeruginosa (AUMC B72), and Serratia marcescens (AUMC B67).

Cell suspension of bacterial strains was prepared from 48-h old cultures on nutrient agar (NA) in sterile water. One milliliter of suspension was added to a Petri dish of $9 \mathrm{~cm}$ diameter and then $15 \mathrm{~mL}$ of NA was poured into the plate. The plate was shaken gently to homogenize the inocula.

Sterile 5-mm filter paper disc (Whatman, UK) was saturated with $10 \mu \mathrm{L}$ of the solution of test compound and gatifloxacin as a reference drug $(53 \mu \mathrm{mol} \mathrm{mL}-1$ in DMSO). In addition, an other disc was impregnated with the solvent (DMSO) and served as a negative control. The discs were then dried for $1 \mathrm{~h}$ and placed in the center of each plate. The seeded plates were incubated at $35 \pm 2{ }^{\circ} \mathrm{C}$ for $24-48 \mathrm{~h}$. The radii of inhibition zones (in $\mathrm{mm}$ ) of triplicate sets were measured and the results are given in Table III.

Antifungal activity. - The synthesized compounds 5a-e to 10a-c were tested for their antifungal activity in vitro in comparison with ketoconazole as a reference drug using the standard agar disc diffusion method (19). Seven pathogenic [Trichophyton rubrum (Castellani) Sabouraud AUMC 1145, and Candida albicans (Robin) Berkhout AUMC 421], phytopathogenic (Fusarium oxysporum Schlechtendal AUMC 208) and food deteriorating fungal species [Aspergillus flavus Link AUMC 3372, Aspergillus niger Van Tieghem AUMC 3364, Geotrichum candidum Link AUMC 228, and Scopulariopsis brevicaulis (Saccardo) Bainier AUMC 363] were used in the study.

Spore suspension in sterile distilled water was prepared from a 2-5 days old culture of the test fungi grown on Sabouraud agar (SA) media. The final spore concentration was nearly $5 \times 10^{4}$ spores $\mathrm{mL}^{-1}$. About $15 \mathrm{~mL}$ of growth medium was added to sterilized Petri dishes of $9 \mathrm{~cm}$ diameter and inoculated with $1 \mathrm{~mL}$ of spore suspension. Plates were shaken gently to homogenize the inocula.

Sterile 5-mm filter paper disc (Whatman) was saturated with $10 \mu \mathrm{L}$ of test compound solution and ketoconazole ( $40 \mu \mathrm{mol} \mathrm{mL} \mathrm{m}^{-1}$ in DMSO). In addition, another disc was impregnated with DMSO and served as a negative control. The discs were then dried for $1 \mathrm{~h}$ 
M. A. Hussein et al.: Synthesis and biological activities of new substituted thiazoline-quinoline derivatives, Acta Pharm. 59 (2009) 365-382.

Table III. Antibacterial activity of compounds 5a-e to $10 a-c$ and gatifloxacin ${ }^{a}$

\begin{tabular}{|c|c|c|c|c|c|c|}
\hline \multicolumn{7}{|c|}{ Inhibition zone (mm) } \\
\hline \multirow[t]{2}{*}{ Compd. $^{\mathrm{a}}$} & \multicolumn{3}{|c|}{ Gram-positive } & \multicolumn{3}{|c|}{ Gram-negative } \\
\hline & B. cereus & S. aureus & M. luteus & E. coli & P. aeroginosa & S. marcescens \\
\hline $5 a$ & 9 & - & - & - & - & - \\
\hline $5 b$ & 9 & - & - & 10 & - & 30 \\
\hline $5 c$ & 18 & - & - & - & - & 22 \\
\hline $5 e$ & 12 & - & - & 18 & - & 10 \\
\hline $6 a$ & 12 & - & - & - & - & 7 \\
\hline $6 b$ & 8 & - & - & - & - & 14 \\
\hline $6 c$ & 13 & - & - & - & - & 14 \\
\hline $6 \mathrm{~d}$ & 8 & - & - & - & - & - \\
\hline $6 e$ & 12 & - & - & - & - & 9 \\
\hline $7 a$ & 8 & - & - & 14 & - & - \\
\hline $7 \mathrm{~b}$ & 10 & - & - & 16 & - & 15 \\
\hline $7 \mathrm{c}$ & 7 & - & - & - & - & - \\
\hline $7 \mathrm{~d}$ & - & - & - & 12 & 12 & - \\
\hline $7 e$ & - & - & - & - & - & 7 \\
\hline $8 a$ & - & 10 & - & 12 & - & - \\
\hline $8 b$ & - & 12 & - & 12 & 8 & - \\
\hline $8 c$ & 7 & - & - & 10 & - & 24 \\
\hline $8 d$ & - & 12 & - & - & 10 & - \\
\hline $8 e$ & 7 & - & - & - & - & - \\
\hline $9 a$ & 10 & - & - & - & - & 20 \\
\hline $9 b$ & 13 & - & - & - & - & 23 \\
\hline $9 c$ & 14 & - & - & - & - & 15 \\
\hline $10 \mathrm{c}$ & 10 & - & - & - & 10 & - \\
\hline Gatifloxacin & 34 & 30 & 19 & 30 & 24 & 34 \\
\hline
\end{tabular}

$(-)-$ no inhibition

a $53 \mu \mathrm{mol} \mathrm{mL}-1$ in DMSO

and placed in the center of each plate. The seeded plates were incubated at $28 \pm 2{ }^{\circ} \mathrm{C}$ for 7 days. The radii of inhibition zones (in $\mathrm{mm}$ ) of triplicate sets were measured at successive intervals during the incubation period and the results are given in Table IV.

\section{Anti-inflammatory activity}

Male adult albino rats (120-150 g) and mice (25-30 g) were obtained from the animal house (Faculty of Medicine, Assiut University, Egypt). Animals were housed in separate cages 6 animals each, in temperature-controlled rooms at $25^{\circ} \mathrm{C}$. Animals were al- 
M. A. Hussein et al.: Synthesis and biological activities of new substituted thiazoline-quinoline derivatives, Acta Pharm. 59 (2009) 365-382.

Table IV. Antifungal activity of test compounds 5a-e to $10 a-c$ and ketoconazole ${ }^{a}$

Inhibition zone $(\mathrm{mm})$

\begin{tabular}{ccccccccc}
\hline Compd. & T. rubrum & C. albicans & F. oxysporum & A. flavus & A. niger & G. candidum & S. brevicaulis \\
\hline $\mathbf{5 a}$ & - & - & 10 & 20 & 18 & - & - \\
$\mathbf{5 b}$ & - & - & 12 & 10 & 15 & 10 & - \\
$\mathbf{5 c}$ & - & - & 13 & 20 & 18 & 15 & 10 \\
$\mathbf{5 e}$ & - & 8 & 13 & 20 & 20 & 12 & - \\
$\mathbf{6 a}$ & - & - & 10 & 12 & 10 & - & 9 \\
$\mathbf{6 b}$ & - & - & 9 & - & 13 & - & 10 \\
$\mathbf{6 c}$ & - & - & - & 10 & 12 & - & 9 \\
$\mathbf{6 e}$ & - & - & 12 & 15 & 10 & - & 10 \\
$7 \mathbf{b}$ & - & - & 10 & - & 12 & - & 9 \\
$\mathbf{8 c}$ & - & 9 & 10 & 8 & 18 & 10 & 7 \\
$\mathbf{8 e}$ & - & - & - & 7 & - & - & - \\
$\mathbf{9 a}$ & - & - & - & 10 & - & - & 20 \\
$\mathbf{9 b}$ & - & - & - & 13 & - & - & 23 \\
$\mathbf{9 c}$ & - & - & - & 14 & - & - & 15 \\
Ketoconazole & - & 32 & 8 & 34 & 24 & 32 & - \\
\hline
\end{tabular}

$(-)$ - no inhibition

a $40 \mu \mathrm{mol} \mathrm{mL}-1$ in DMSO

lowed free access to rodent chow and water and maintained at a $12 \mathrm{~h}$ light/dark cycle. Work was conducted in accordance with the internationally accepted principles for laboratory animals' use and care as found in the European Community Guidelines (20) and Institutional Ethical Committee Approval was obtained.

Indomethacin (Liometacin ${ }^{\circledR}$ vial, Nile Company, Egypt), carrageenan (Sigma, USA), sodium carboxymethylcellulose $(\mathrm{NaCMC})$ and normal saline were obtained from the local market.

All tested compounds and the reference drug were suspended in $1 \% \mathrm{NaCMC}$ in normal saline. Suspensions of the tested compounds, reference drug and $1 \% \mathrm{NaCMC}$ -saline solution (negative control) were injected i.p. (1 mL each).

The anti-inflammatory activity of the newly synthesized compounds 5a-e to $10 a-c$ together with the intermediate compounds 3a-f was evaluated according to the carrageenan induced paw edema method in comparison with indomethacin as a reference drug (21). The test is based on pedal inflammation in rat paws induced by subplantar injection of carrageenan suspension $(0.2 \mathrm{~mL}$ of $1 \%$ solution in normal saline) into the right hind paw of the rats. Male adult albino rats were divided into groups of four animals each. The rat paw thickness was measured with a Vernier caliper (SMIEC, China) before and $1 \mathrm{~h}$ after carrageenan injection to detect the carrageenan induced inflammation. Each tested compound, at a dose of $0.02 \mathrm{mmol} \mathrm{kg}^{-1}$, was injected i.p. to thirty four different groups of rats $1 \mathrm{~h}$ after carrageenan injection. Control group received the vehicle (1\% 
sodium carboxymethylcellulose ( $\mathrm{NaCMC}$ ) solution in normal saline), while the reference group received indomethacin i.p. at a dose of $0.02 \mathrm{mmol} \mathrm{kg}-1$.

The difference between the thicknesses of the two paws was taken as a measure of edema. The measurement was carried out at $0,0.5,1,2,3,4$ and $5 \mathrm{~h}$ after injection of the tested compounds, reference drug and control. The results are listed in Table V.

\section{Gastric ulceration}

Ulcerogenicity of the most active anti-inflammatory compounds $6 \mathbf{b}$ and $9 \mathbf{e}$ was determined on male adult albino rats according to a reported method (22).

Gastric lesions on the mucosa were determined using a stereoscopic microscope (XJP-XSC-195-40X, Jiangsu, China). Observation of gastrointestinal mucosa for the presence of lesions following oral administration of graded doses of the tested compounds as well as the reference drug was taken as an indication of ulcerogenic effects. Both the frequency of ulceration (expressed as the ratio of ulcerated animals) and the severity of ulceration (expressed as the ulcer index) were used for comparison of the tested compounds and indomethacin. Male albino rats were fasted for $24 \mathrm{~h}$. Compounds $6 \mathbf{b}, 9 \mathbf{e}$ and indomethacin were administered orally at doses of 10,30 , and $50 \mathrm{mg} \mathrm{kg}^{-1}$ as suspensions in a $1 \% \mathrm{NaCMC}$-saline solution to groups of rats of 6 animals each. After $6 \mathrm{~h}$, the animals were sacrificed, the stomachs were removed and gastric lesions on the mucosa were determined using a stereoscopic microscope. Ulcer was defined as at least one lesion of $0.5 \mathrm{~mm}$ or more in length. All lesions of more than $0.1 \mathrm{~mm}$ in length were summed up to obtain the ulcer index and the results are listed in Table VI.

\section{Acute toxicity}

The median lethal dose $\left(L D_{50}\right)$ of the most active and safe compounds ( $6 \mathbf{b}$ and $\left.9 \mathbf{e}\right)$ was determined in mice (23). Groups of male adult albino mice of four animals each, were injected i.p. with graded doses of the tested compounds. The percentage mortality in each group of animals was determined $72 \mathrm{~h}$ after the injection.

\section{Partitioning data}

The $\log P$ values of the tested compounds 5a-e to 10a-c were computed by a routine method called calculated $\log P(C \log P)$ (contained in the PC-software package McLogP 2.0, BioByte Corp., CA, USA, Table I). The molecular structure is entered into the program, which computers the $\log P$ based on the fragment method developed by Leo (24).

\section{RESULTS AND DISCUSSION}

\section{Chemistry}

Target compounds, 5-acyl-8-hydroxyquinoline-2-(3'-substituted-4'-aryl-2,3-dihydrothiazol-2'-ylidene) hydrazones 5a-e to 8a-e and 10a-c were prepared by refluxing the appropriate 5-acyl-8-hydroxyquinoline-4-substituted thiosemicarbazones $3 \mathbf{a}-\mathbf{d}$ and $\mathbf{3 f}$ and 
phenacyl bromides 4a-e in the presence of anhydrous sodium acetate in absolute ethanol. The 5-acetyl-8-hydroxyquinoline-2-(3'-phenyl-4'-aryl-2,3-dihydrothiazol-2'-ylidene) hydrazones 9a-e were prepared by stirring 5-acetyl-8-hydroxyquinoline-4-phenyl thiosemicarbazone $3 \mathrm{e}$ with appropriate phenacyl bromide 4a-e in ethanol at room temperature. Structures of the target compounds $5 \mathrm{a}-\mathrm{e}$ to $10 \mathrm{a}-\mathrm{c}$ were confirmed by IR, ${ }^{1} \mathrm{H}$ NMR, MS in addition to elemental analysis. IR spectra of compounds 5a-e to 10a-c were characterized by a lack of characteristic bands of NH and NCS functional groups and exhibited a band attributed to $\mathrm{C}=\mathrm{N}$ stretching at $1634-1562 \mathrm{~cm}^{-1}$. Moreover, all compounds showed the characteristic band at 3545-3410 $\mathrm{cm}^{-1}$ (OH stretching of 8-hydroxyquinoline) in addition to its bending at $769-650 \mathrm{~cm}^{-1}$. ${ }^{1} \mathrm{H}$ NMR spectra of the prepared products (Table II) showed a general pattern for the 8-hydroxyquinoline characterized by the presence of two doublet signals at 10.17-10.73 ppm and at 9.33-9.80 ppm corresponding to $\mathrm{H}-2$ and $\mathrm{H}-4$ of quinoline, respectively, a multiplet at 7.10-8.93 ppm corresponding to the phenyl group, the $\mathrm{OH}$ group (exchangeable), and $\mathrm{H}-3, \mathrm{H}-6$ and $\mathrm{H}-7$ of quinoline, a singlet signal at $6.20-6.70 \mathrm{ppm}$ corresponding to the thiazoline proton, and a singlet signal at 2.60-2.90 ppm corresponding to $\mathrm{CH}_{3}$, in addition to the disappearance of signals corresponding to the N2-H and N4-H signals. Also, the structure of the target compounds was confirmed by MS of representative compounds $5 b, 6 c, 7 a, 7 c, 8 b, 9 c$ and $10 c$. MS for compound $5 b$ revealed the molecular ion peak $\mathrm{M}^{+}$at $m / z 452$ (63.3\%) corresponding to the relative molecular mass of this compound (452.03) and a base peak at $\mathrm{m} / z 170$ (100\%). It also showed the $\mathrm{M}^{+}+2$ peaks of ${ }^{81} \mathrm{Br}$ and the ${ }^{34} \mathrm{~S}$ peak at $\mathrm{m} / \mathrm{z} 454(71.9 \%)$. MS for compound 6c revealed the molecular ion peak $\mathrm{M}^{+}$at $\mathrm{m} / \mathrm{z} 422$ (54.2\%) corresponding to the $M_{\mathrm{r}}$ of this compound (422.10) and a base peak at $m / z 170(100 \%)$. It also showed the $\mathrm{M}^{+}+2$ peak of ${ }^{37} \mathrm{Cl}$ and the ${ }^{34} \mathrm{~S}$ peak at $\mathrm{m} / z$ $424(23.7 \%)$. MS for compound 7a revealed the molecular ion peak $\mathrm{M}^{+}$at $m / z 400(100 \%)$ corresponding to the $M_{\mathrm{r}}$ of this compound (400.14), which is also the base peak. MS for compound $7 \mathrm{c}$ revealed the molecular ion peak $\mathrm{M}^{+}$at $\mathrm{m} / \mathrm{z} 434(100 \%)$ corresponding to the $M_{\mathrm{r}}$ of this compound (434.10), which is also the base peak. It also showed the $\mathrm{M}^{+}+2$ peak of ${ }^{37} \mathrm{Cl}$ peak at $\mathrm{m} / z 436(36.1 \%)$. MS for compound $8 \mathbf{b}$ revealed the molecular ion peak $\mathrm{M}^{+}$at $\mathrm{m} / \mathrm{z} 520(14.8 \%)$ corresponding to the $M_{\mathrm{r}}$ of this compound (520.09) and a base peak at $\mathrm{m} / \mathrm{z} 55$ (100\%). It also showed the $\mathrm{M}^{+}+2$ peak of ${ }^{81} \mathrm{Br}$ peak at $\mathrm{m} / \mathrm{z} 522(14.9 \%)$. MS for compound 9c revealed the molecular ion peak $\mathrm{M}^{+}$at $m / z 470(100 \%)$ corresponding to the $M_{\mathrm{r}}$ of this compound (470.10), which is also the base peak. It also showed the $\mathrm{M}^{+}+2$ peak of ${ }^{37} \mathrm{Cl}$ peak at $m / z 472(38.7 \%)$. MS for compound 10c revealed the molecular ion peak $\mathrm{M}^{+}$at $\mathrm{m} / \mathrm{z} 538(54.6 \%)$ corresponding to the $M_{\mathrm{r}}$ of this compound (538.16) and a base peak at $m / z 247(100 \%)$. It also showed the $\mathrm{M}^{+}+2$ peak of ${ }^{37} \mathrm{Cl}$ peak at $\mathrm{m} / \mathrm{z} 540(23.7 \%)$.

\section{Antimicrobial activity}

Results of the antibacterial activity (Table III) indicated that M. luteus was completely resistant to the tested compounds, while B. cereus, E. coli and S. marcescens were the most sensitive organisms to the tested compounds.

Compounds $5 \mathrm{~d}, \mathbf{9 d}, \mathbf{9 e}, \mathbf{1 0 a}$ and $\mathbf{1 0 b}$ were completely inactive against the tested organisms. Also the test compounds were most inactive against $S$. aureus and $P$. aeroginosa except for compounds $\mathbf{7 d}, \mathbf{8 a}, \mathbf{8 b}, \mathbf{8 d}$ and $\mathbf{1 0}$. On the other hand, tested compounds were active against B. cereus, E. coli and S. marcescens since they showed $20-88 \%$ antibac- 
terial activity of that exerted by gatifloxacin. The most active compounds were $\mathbf{5 b}, \mathbf{5 c}$, $5 \mathbf{e}, 7 \mathbf{b}, \mathbf{8 c}, \mathbf{9 a}$ and $\mathbf{9 b}$. The latter contain $\mathrm{Cl}, \mathrm{Br}$ or $\mathrm{OCH}_{3}$ as an $\mathrm{R}^{2}$ substituent. It was also noticed that the introduction of a phenyl group in compounds 9a-e resulted in a decrease of their antibacterial activity. Also, the cyclohexyl substituent at $\mathrm{R}^{1}$ seems to be crucial for the antibacterial activity.

Results of antifungal activity (Table IV) revealed that all the tested compounds were inactive against $T$. rubrum. They were also inactive against $C$. albicans, except for compounds $\mathbf{5 e}$ and $\mathbf{8 c}$ and against $\mathrm{G}$. candidum, except for compounds $\mathbf{5 b}, \mathbf{5 c}, \mathbf{5 e}$, and $\mathbf{8 c}$ which showed 31-47 \% activity compared to ketoconazole. Several compounds showed weak to moderate activity against $S$. brevicaulis, while the reference drug was completely inactive. Important to say, compounds $5 \mathrm{a}-\mathrm{c}, 5 \mathrm{e}, 6 \mathrm{a}, \mathbf{6 b}, \mathbf{6 e}, 7 \mathrm{~b}$ and $8 \mathrm{c}$ were even more active than ketoconazole against $F$. oxysporum. The most active compounds were $5 \mathbf{c}, \mathbf{6 e}, \mathbf{7 b}$, $8 \mathrm{c}$ and $\mathbf{9 b}$ comprising $\mathrm{Cl}, \mathrm{Br}$ or $\mathrm{OCH}_{3}$ as an $\mathrm{R}^{2}$ substituent.

\section{Anti-inflammatory activity}

Results of anti-inflammatory activity (Table V) revealed that all the tested compounds showed a gradual increase of anti-inflammatory activity up to its maximum after $4 \mathrm{~h}$. After $5 \mathrm{~h}$, almost all the newly synthesized compounds showed 51-78\% edema inhibition (edema inhibition of indomethacin at the time is $80.9 \%$ ). Accordingly, comparison between the tested compounds was made at the moment of the highest activity. Compounds 3a-f, 5a-e, 6a-e, 7a-e, 8a-e, 9a-e and 10 a-c showed 63-104\% of the anti-inflammatory activity of indomethacin after $4 \mathrm{~h}$.

It is noteworthy that cyclization of thiosemicarbazone derivatives 3a-f into the corresponding thiazoline derivatives $5 \mathrm{a}-\mathrm{e}$ to $\mathbf{1 0 a - c}$ resulted in a marked increase of anti-inflammatory activity, which is similar to previous findings (21). Also, most of the compounds bearing $p-\mathrm{Cl}, p-\mathrm{Br}$, or $p-\mathrm{OCH}_{3}$ substituents on the phenyl group showed high anti-inflammatory activity indicating the crucial role of halogen or $\mathrm{OCH}_{3}$ for anti-inflammatory activity, which is similar to previous data (25).

\section{Ulcerogenic effect and acute toxicity}

The most active anti-inflammatory compounds $\mathbf{6 b}$ and $9 \mathrm{e}$ and indomethacin were evaluated for their ulcerogenic effect (Table VI). Data revealed that compounds $\mathbf{6} \mathbf{b}$ and 9e had no ulcerogenic effect at the treating doses of 10 and $30 \mathrm{mg} \mathrm{kg}^{-1}$ while at higher doses (50 $\mathrm{mg} \mathrm{kg}^{-1}$ ) they exhibited lower ulcerogenic activity compared to indomethacin. Indomethacin caused ulceration at the tested dose levels and increased in frequency and severity at higher doses.

In addition, the median lethal doses $\left(L D_{50}\right)$ of compounds $6 \mathbf{b}$ and $9 \mathbf{e}$ were evaluated and it was found that they were non-toxic at doses up to $400 \mathrm{mg} \mathrm{kg}^{-1}$ (i.p.) while the reported $L D_{50}$ of indomethacin is $13 \mathrm{mg} \mathrm{kg}^{-1}$ (i.p.) (26). 
M. A. Hussein et al.: Synthesis and biological activities of new substituted thiazoline-quinoline derivatives, Acta Pharm. 59 (2009) 365-382.

Table V. Inhibitory effect of test compounds 5 a-e to $10 a-c$ and indomethacin ${ }^{a}$ upon carrageenan induced paw edema in rats

\begin{tabular}{|c|c|c|c|c|c|c|c|}
\hline \multirow{2}{*}{ Compd. ${ }^{a}$} & \multicolumn{7}{|c|}{ Edema inhibition (\%) } \\
\hline & $0 \mathrm{~h}$ & $0.5 \mathrm{~h}$ & $1 \mathrm{~h}$ & $2 \mathrm{~h}$ & $3 \mathrm{~h}$ & $4 \mathrm{~h}$ & $5 \mathrm{~h}$ \\
\hline $3 a$ & 4.4 & 30.9 & 42.5 & 50.2 & 56.5 & 52.9 & 50.2 \\
\hline $3 b$ & 7.4 & 31.2 & 35.0 & 39.7 & 47.3 & 47.6 & 47.6 \\
\hline $3 c$ & 3.7 & 31.0 & 31.0 & 43.2 & 44.0 & 47.5 & 39.1 \\
\hline $3 d$ & 3.7 & 31.2 & 31.2 & 39.7 & 50.4 & 58.8 & 61.6 \\
\hline $3 e$ & 4.7 & 30.85 & 34.73 & 39.42 & 53.33 & 58.55 & 55.75 \\
\hline $3 f$ & 4.4 & 26.9 & 30.9 & 35.8 & 47.0 & 58.6 & 55.8 \\
\hline $5 a$ & 2.2 & 31.2 & 31.2 & 39.7 & 59.9 & 61.6 & 44.8 \\
\hline $5 b$ & 4.4 & 30.9 & 30.9 & 43.0 & 59.6 & 66.9 & 64.1 \\
\hline $5 c$ & 3.5 & 46.4 & 50.2 & 61.0 & 69.1 & 69.7 & 66.9 \\
\hline $5 d$ & 2.2 & 38.9 & 38.9 & 43.3 & 63.0 & 55.9 & 53.2 \\
\hline $5 e$ & 2.2 & 23.3 & 38.8 & 43.2 & 56.6 & 64.2 & 57.7 \\
\hline $6 a$ & 5.6 & 31.0 & 46.5 & 50.4 & 53.5 & 55.9 & 50.3 \\
\hline $6 b$ & 8.2 & 46.7 & 58.3 & 64.9 & 69.3 & 78.3 & 69.9 \\
\hline $6 c$ & 7.1 & 50.2 & 57.9 & 61.0 & 69.1 & 72.5 & 72.5 \\
\hline $6 \mathrm{~d}$ & 8.1 & 38.8 & 42.6 & 46.8 & 56.6 & 58.7 & 53.1 \\
\hline $6 e$ & 8.1 & 34.9 & 54.3 & 61.2 & 66.0 & 61.5 & 55.9 \\
\hline $7 a$ & 4.4 & 38.6 & 42.5 & 50.2 & 56.5 & 58.6 & 52.9 \\
\hline $7 b$ & 4.7 & 42.8 & 50.5 & 57.7 & 65.7 & 61.6 & 55.9 \\
\hline $7 c$ & 2.0 & 42.6 & 42.6 & 46.8 & 56.6 & 72.6 & 69.8 \\
\hline $7 d$ & 3.7 & 31.0 & 38.8 & 57.6 & 56.6 & 50.3 & 50.3 \\
\hline $7 e$ & 3.5 & 30.9 & 38.6 & 46.6 & 56.5 & 72.5 & 69.9 \\
\hline $8 a$ & 4.5 & 31.0 & 42.6 & 46.8 & 59.8 & 67.0 & 69.8 \\
\hline $8 b$ & 2.0 & 38.6 & 42.5 & 50.2 & 69.1 & 72.5 & 69.7 \\
\hline $8 c$ & 4.4 & 38.8 & 34.9 & 46.6 & 56.5 & 66.9 & 69.7 \\
\hline $8 d$ & 4.7 & 38.8 & 34.9 & 46.8 & 62.9 & 69.8 & 72.6 \\
\hline $8 \mathbf{e}$ & 3.9 & 31.2 & 42.8 & 54.1 & 66.2 & 75.5 & 69.9 \\
\hline $9 a$ & 2.2 & 31.2 & 31.2 & 39.7 & 53.6 & 61.6 & 64.4 \\
\hline $9 b$ & 1.8 & 31.0 & 38.8 & 46.8 & 62.9 & 67.0 & 61.5 \\
\hline $9 c$ & 2.0 & 42.5 & 42.5 & 50.2 & 69.1 & 72.5 & 69.9 \\
\hline $9 d$ & 3.7 & 31.0 & 31.0 & 39.6 & 53.5 & 61.5 & 55.9 \\
\hline $9 e$ & 4.7 & 42.8 & 46.7 & 61.3 & 72.5 & 75.5 & 69.9 \\
\hline $10 a$ & 7.1 & 34.7 & 46.4 & 50.2 & 72.2 & 75.3 & 75.3 \\
\hline $10 \mathrm{~b}$ & 7.9 & 38.6 & 50.2 & 64.6 & 69.1 & 72.5 & 78.1 \\
\hline $10 \mathrm{c}$ & 7.4 & 27.3 & 38.9 & 54.1 & 53.6 & 58.8 & 53.2 \\
\hline Negative control & - & - & - & - & - & - & - \\
\hline Indomethacin & 7.9 & 42.5 & 61.9 & 64.6 & 72.2 & 75.3 & 80.9 \\
\hline
\end{tabular}

a $0.02 \mathrm{mmol} \mathrm{kg}^{-1}$ in $1 \% \mathrm{NaCMC}$ solution in normal saline 
M. A. Hussein et al.: Synthesis and biological activities of new substituted thiazoline-quinoline derivatives, Acta Pharm. 59 (2009) 365-382.

Table VI. Ulcerogenic effect of compounds $6 \boldsymbol{b}, 9 e$ and indomethacin

\begin{tabular}{cccc}
\hline Compd. & Dose $\left(\mathrm{mg} \mathrm{kg}^{-1}\right)$ & Ratio of ulcerated animals & Ulcer index (mean $\pm \mathrm{SD})$ \\
\hline \multirow{2}{*}{ 6b } & 10 & $0 / 6$ & 0 \\
& 30 & $4 / 6$ & $1.15 \pm 0.17$ \\
& 50 & $6 / 6$ & $1.42 \pm 0.67$ \\
$9 \mathbf{9}$ & 10 & $0 / 6$ & 0 \\
& 30 & $2 / 6$ & $0.50 \pm 0.22$ \\
& 50 & $6 / 6$ & $0.75 \pm 0.23$ \\
Indomethacin & 10 & $4 / 6$ & $1.20 \pm 0.24$ \\
& 30 & $6 / 6$ & $1.50 \pm 0.51$ \\
\hline
\end{tabular}

\section{CONCLUSIONS}

A number of 5-acyl-8-hydroxyquinoline-2-(3'-substituted-4'-aryl-2,3-dihydro-thiazol-2'-ylidene)hydrazones, 5 a-e to $\mathbf{1 0 a - c}$, were prepared and tested for their antibacterial activities. They showed moderate activity against most of the tested bacterial strains but showed no antibacterial activity against $M$. luteus. The antifungal data of the tested compounds showed that the $N$-methyl and $N$-ethyl series were the most active compounds and many compounds showed better antifungal activity against F. oxysporum than ketoconazole; some also showed activity against S. brevicaulis (c.f. ketoconazole). On the other hand, the tested compounds showed a gradual increase in their anti-inflammatory activity, reaching its maximum after $4 \mathrm{~h}$ in the carrageenan induced paw edema. Cyclization of thiosemicarbazone derivatives into the corresponding thiazoline derivatives resulted in a marked increase in anti-inflammatory activity. The $p$-bromo- $p$-chloro- and $p$-methoxy-phenyl derivatives showed the highest activity, which indicates the crucial role of halogen or $\mathrm{OCH}_{3}$. Compounds $\mathbf{6 b}, \mathbf{c}, \mathbf{7 b}, \mathbf{c}, \mathbf{e}, \mathbf{8 b}, \mathbf{e}, \mathbf{9 c}, \mathbf{e}$, and $\mathbf{1 0 a}, \mathbf{b}$ showed activity comparable to that of indomethacin as the reference drug.

The most active anti-inflammatory compounds $\mathbf{6 b}$ and $9 \mathbf{e}$ were safer than indomethacin in ulcerogenic liability in frequency and severity. In addition, the $L D_{50}$ of compounds $6 \mathbf{b}$ and $9 \mathbf{e}$ showed that they were non-toxic at doses up to $400 \mathrm{mg} \mathrm{kg}^{-1}$ (i.p.) whereas the $L D_{50}$ of indomethacin is only $13 \mathrm{mg} \mathrm{kg}^{-1}$ (i.p.).

Acknowledgments. - The authors greatefully acknowledge Dr. Mahran S. Abdel-Rahman, Faculty of Medicine, Assiut University, Egypt, for his help in performing the pharmacological screening. Great thanks are also due to the staff members of the Assiut University Micological Center (AUMC), Faculty of Science, Assiut University, Egypt, for performing the antimicrobial tests. The authors also thank the Micro Analytical Center, Faculty of Science, Cairo University, Egypt, for carrying out the mass spectral analyses and some of the elemental analyses and also the Unit of Microanalysis, Assiut University, Egypt, for carrying out some of the elemental analyses. 


\section{REFERENCES}

1. S. G. Abdel-Moty, M. H. Abdel-Rahman, H. A. Elsherief and A. H. N. Kafafy, Synthesis of some quinoline thiosemicarbazone derivatives of potential antimicrobial activity, Bull. Pharm. Sci. (Assiut University) 28 (2005) 79-93.

2. R. Vlahov, St. Parushev, J. Vlahov, P. Nickel and G. Snatzke, Synthesis of some new quinoline derivatives - potential antimalarial drugs, Pure Appl. Chem. 62 (1990) 1303-1306; DOI: 10.1351/ pac199062071303.

3. M. Normand-Bayle, C. Bénard, V. Zouhiri, J. Mouscadet, H. Leh, C. Thomas, G. Mbemba, D. Desmaële and J. d'Angelo, New HIV-1 replication inhibitors of the styryquinoline class bearing aroyl/acyl groups at the C-7 position: synthesis and biological activity, Bioorg. Med. Chem. Lett. 15 (2005) 4019-4022; DOI: 10.1016/j.bmcl.2005.06.036.

4. S. T. Hazeldine, L. Polin, J. Kushner, K. White, T. H. Corbett, J. Biehl and J. P. Horwitz, Part 3: Synthesis and biological evaluation of some analogs of the antitumor agents, 2-\{4-[(7-chloro-2-quinoxalinyl)oxy]phenoxy\}propionic acid, and 2-\{4-[7-bromo-2-quinolinyl)-oxy]phenoxy\}propionic acid, Bioorg. Med. Chem. 13 (2005) 1069-1081, DOI: 10.1016/j.bmc.2004.11.034.

5. J. He, L. Yun, R. Yang, Z. Xiao, J. Cheng, W. Zhou and Y. Zhang, Design, synthesis, and biological evaluation of novel 4-hydro-quinoline-3-carboxamide derivatives as an immunomodulator, Bioorg. Med. Chem. Lett. 15 (2005) 2980-2985; DOI: 10.1016/j.bmcl.2005.04.040.

6. D. V. Kravchenko, V. V. Kysil, A. P. Ilyn, S. E. Tkachenko, S. Maliarchouk, I. M. Okun and A. V. Ivachtchenko, 1,3-Dioxo-4-methyl-2,3-dihydro-1H-pyrrolo[3,4-c]quinolines as potent caspase-3 inhibitors, Bioorg. Med. Chem. Lett. 15 (2005) 1841-1845; DOI: 10.1016/j.bmcl.2005.02.027.

7. Z. Dardari, M. Lemrani, A. Bahloul, A. Sebban, M. Hassar, S. Kitane, M. Berrada and M. Boudouma, Antileishmanial activity of a new 8-hydroxyquinoline derivative designed 7-[5-(3'-phenylisoxazolino)methyl]-8-hydroxyquinoline: preliminary study, Farmaco 59 (2004) 195-199; DOI: 10.1016/j.farmac.2003.11.001.

8. F. E. Goda, A. A. Abdel-Aziz and H. A. Ghoneim, Synthesis and biological evaluation of novel 6-nitro-5-substituted aminoquinolines as local anesthetic and anti-arrhythmic agents: molecular modeling study, Bioorg. Med. Chem. 13 (2005) 3175-3183; DOI: 10.1016/j.bmc.2005.02.050.

9. L. Savini, L. Chiasserini, C. Pellerano, W. Filippelli and G. Falcone, Synthesis and pharmacological activity of 1,2,4-triazolo[4,3-a]quinolines, Farmaco 56 (2001) 939-945; DOI: 10.1016/S0014$-827 X(01) 01166-1$.

10. A. M. Omar, I. C. Ahmed, A. M. Hassan, O. M. AboulWafa, H. Abou-Shleib and K. A. Ismail, Synthesis and evaluation for antibacterial and antifungal activities of new 1-phenylhydrazono-2-(substituted thiocarbamoyl)hydrazonopyruvaldehyde and the corres- ponding thiazoline and thiazolidinone derivatives, Alex. J. Pharm. Sci. 4 (1990) 182-186.

11. D. L. Klayman, J. P. Scovill, J. Bruce and J. F. Bartosevich, 2-Acetylpyridine thiosemicarbazones, 8. Derivatives of 1-acetylisoquinoline as potential antimalarial agents, J. Med. Chem. 27 (1984) 84-87; DOI: 10.1021/jm00367a018.

12. S. Sharma, F. Athar, M. R. Maurya, F. Naqvi and A. Azam, Novel bidentate complexes of Cu(II) derived from 5-nitrofuran-2-carboxaldehyde thiosemicarbazones with antiamoebic activity against E. histolytica, Eur. J. Med. Chem. 40 (2005) 557-562, DOI: 10.1016/j. ejmech.2005.01.003.

13. H. Y. Hassan, Synthesis and chelating properties of substituted formyl pyridine thiosemicarbazones of potential biological activity, Bull. Pharm. Sci. (Assiut University) 22 (1999) 97-108.

14. S. M. Sondhi, N. Singh, A. M. Lahoti, K. Bajaj, A. Kumar, O. Lozach and L. Meijer, Synthesis of acridinyl-thiazolino derivatives and their evaluation for anti-inflammatory, analgesic and kinase inhibition activities, Bioorg. Med. Chem. 13 (2005) 4291-4299; DOI: 10.1016/j.bmc.2005.04.017. 
M. A. Hussein et al.: Synthesis and biological activities of new substituted thiazoline-quinoline derivatives, Acta Pharm. 59 (2009) 365-382.

15. G. Mahler, G. Serra, S. Dematteis, J. Saldaña, L. Domínguez and E. Manta, Synthesis and biological evaluation of simplified mycothiazole analogues, Bioorg. Med. Chem. Lett. 16 (2006) 1309-1311; DOI: 10.1016/j.bmcl.2005.11.072.

16. M. Shih and F. Ke, Synthesis and evaluation of antioxidant activity of sydnonyl substituted thiazolidinone and thiazoline derivatives, Bioorg. Med. Chem. 12 (2004) 4633-4643; DOI: 10.1016/ j.bmc.2004.06.033.

17. D. Barton and W. D. Ollis, Comprehensive Organic Chemistry (Ed. D. N. Jones), Vol. 3, Pergamon Press, New York 1979, p. 453.

18. A. I. Vogel, A. R. Tatchell, B. S. Furnis, A. J. Hannaford, P. W. G. Smith, Vogel's Textbook of Practical Organic Chemistry, 5 ${ }^{\text {th }}$ ed, Harlow Pearson Ed. Ltd. 1989, p. 1052.

19. W. Hewitt, An Introduction to Quantitative Principles and Evaluation, in Microbiological Assay, Academic Press, New York 1977.

20. B. Tan, Guidelines on the Care and Use of Animals for Scientific Purposes, National Advisory Committee for Laboratory Animals, Singapore 2004.

21. L. V. Nargund, G. R. Reddy and V. Hariprasad, Anti-inflammatory activity of substituted 1,3,4-oxadiazoles, J. Pharm. Sci. 83 (1994) 246-248; DOI: 10.1002/jps.2600830226.

22. H. Ikuta, H. Shirota, S. Kobayashi, Y. Yamagishi, K. Yamada, I. Yamatsu and K. Katayama, Synthesis and anti-inflammatory activities of 3-(3,5-di-tert-butyl-4-hydroxybenzylidene)pyrrolidin-2-ones, J. Med. Chem. 30 (1987) 1995-1998.

23. F. Sztaricskai, I. E. Takács, F. Pusztai, G. Szabó and I. Csípõ, Antiulcer effect of the $N$-and O- $\beta$-D-glucopyranosides of 5-aminosalicylic acid, Arch. Pharm. Pharm. Med. Chem. 332 (1999) 321-326.

24. J. Leo, Calculating log $P_{\text {oct }}$ from structures, Chem. Rev. 93 (1993) 1281-1306; DOI: 10.1021/ cr00020a001.

25. G. Dannhardt, W. Kiefer, G. Krämer, S. Maehrlein, U. Nowe and B. Fiebich, The pyrrole moiety as a template for Cox-1/Cox-2 inhibitors, Eur. J. Med. Chem. 35 (2000) 499-510; DOI: 10.1016/ S0223-5234(00)00150-1.

26. M. J. O'Neil, A. Smith, P. E. Heckelman and S. Budavari (Eds), The Merck Index:, $13^{\text {th }}$ ed, Merck Inc., Whitehouse Station (NJ) 2001, p. 892.

\author{
$S A \check{Z} E T A K$
}

\title{
Sinteza i potencijalno biološko djelovanje novih supstituiranih derivata tiazolin-kinolina
}

MOSTAFA A. HUSSEIN, ABDEL-HAMID N. KAFAFY, SAMIA G. ABDEL-MOTY i OLA MOHAMED F. ABOU-GHADIR

5-Acil-8-hidroksikinolin-2-(3'-supstituirani-4'-aril-2,3-dihidrotiazol-2'-iliden) hidrazoni 5a-e do 10a-c pripravljeni su reakcijom odgovarajućih 5-acil-8-hidroksikinolin-4-supstituiranih tiosemikarbazona 3a-e i fenacil bromida 4a-e. Strukture novih spojeva potvrđene su na temelju spektralnih i elementarnih analiza. Dvadeset osam novih spojeva testirano je na potencijalno antimikrobno djelovanje. Većina spojeva pokazuje slabo do umjereno antibakterijsko djelovanje protiv većine testiranih bakterijskih sojeva u usporedbi s gatifloksacinom kao referentim lijekom, te slabo do umjereno antifungalno djelovanje protiv gljivica u usporedbi s ketokonazolom kao referentnim lijekom. Testovi na protuupalno djelovanje pokazuju da većina spojeva posjeduje dobro ili snažno protuupalno djelo- 
M. A. Hussein et al.: Synthesis and biological activities of new substituted thiazoline-quinoline derivatives, Acta Pharm. 59 (2009) 365-382.

vanje u usporedbi s indometacinom. Ulcerogeno djelovanje i srednje letalne doze $\left(L D_{50}\right)$ najaktivnijih spojeva $\mathbf{6 b}$ i 9 e određene su na miševima. Rezultati pokazuju da su netoksični u dozama do $400 \mathrm{mg} \mathrm{kg}^{-1}$ nakon i.p. primjene.

Ključne riječi: kinolin, tiosemikarbazon, tiazolin, fenacil bromid, antimikrobno djelovanje, protuupalno djelovanje

Department of Pharmaceutical Organic Chemistry, Faculty of Pharmacy, Assiut University Assiut-71526, Egypt 